\title{
PENERAPAN MEDIA RODA PUTAR PUZZLE PINTAR UNTUK MENINGKATKAN HASIL BELAJAR SISWA SEKOLAH DASAR
}

\author{
La Ili $^{1}$, Gusti Handayani², Nanda Saputra ${ }^{3}$ \\ 1. Universitas Halu Oleo,Indonesia, ${ }^{2,3}$ STIT Al-Hilal Sigli, Indonesia.
}

Email: laili.190617@gmail.com ${ }^{1}$, gustyharun02@gmail.com², nandasaputra680@gmail.com³.

\begin{abstract}
This study aims to: (1) increase student activity during the learning activities of sub-theme 1 energy sources; (2) Improve learning outcomes in sub-theme 1 energy sources; and (3) Producing learning media for sub-theme 1 sources of innovative energy that can increase motivation and learning outcomes in sub-theme 1 energy sources. This type of research is a classroom action research using the Kemmis and Mc. Taggart. This media is motivated by the students' mastery of the subject matter is low, the activity of students during the learning process is very lacking, students are less interested in the methods and media used by researchers. This innovative work consists of two types of media, namely the Spinning Wheel and the Smart Puzzle. This rotating wheel uses iron and used parabolic plates. Meanwhile, this Smart Puzzle is made from Styrofoam and Asturo paper. The wheel will stop pointing to a source of energy for the students to arrange their smart puzzles. The results obtained in the practical application of this media are that it can increase motivation and learning achievement in sub-theme 1 energy sources for fourth grade students of SDN 2 Sigli. It is proven in the first cycle of 33 students who achieved complete learning, 16 students or $48.5 \%$ obtained an average score of 68.2. Then the complete students increased again in the second cycle to 28 students or $84.9 \%$ with an average score of 77.6 which exceeded the indicator achievement target of 70. Based on the results of observations, this learning process was in a good category.
\end{abstract}

Keywords: Smart puzzle rotating wheel, Learning outcomes

\begin{abstract}
ABSTRAK
Penelitian ini bertujuan untuk: (1) meningkatkan keaktifan siswa selama kegiatan pembelajaran sub tema 1 sumber energi; (2) Meningkatkan hasil belajar sub tema 1 sumber energi; dan (3) Menghasilkan media pembelajaran sub tema 1 sumber energi inovatif yang dapat meningkatkan motivasi dan hasil belajar sub tema 1 sumber energi. Jenis penelitian ini adalah penelitian tindakan kelas dengan menggunakan model Kemmis dan Mc. Taggart. Media ini dilatarbelakangi penguasaan siswa terhadap materi pelajaran rendah, keaktifan siswa selama proses pembelajaran sangat kurang, siswa kurang tertarik pada metode dan media yang digunakan peneliti. Karya inovasi ini terdiri dari dua jenis media yaitu Roda Putar dan Puzzle Pintar. Roda Putar ini bahan bakunya menggunakan besi dan plat bekas parabola. Sedangkan Puzzle Pintar ini dibuat dari styrofoam dan kertas asturo. Roda Putar akan berhenti mengarah pada suatu sumber energi untuk disusun puzzle pintarnya oleh siswa. Adapun hasil yang diperoleh dalam aplikasi praktis media ini adalah dapat meningkatkan motivasi dan prestasi belajar sub tema 1 sumber energi siswa kelas IV SDN 2 Sigli. Terbukti pada siklus I dari 33 siswa yang mencapai tuntas belajar, 16 siswa atau 48,5\% memperoleh nilai rata-rata 68,2. Kemudian siswa tuntas meningkat lagi pada siklus kedua menjadi 28 siswa atau 84,9\% dengan nilai ratarata 77,6 yang melampaui target pencapaian indikator sebesar 70. Berdasarkan hasil observasi, proses pembelajaran ini masuk kategori baik.
\end{abstract}

Kata kunci : roda putar puzzle pintar, hasil belajar

\section{PENDAHULUAN}

Pelaksanaan kegiatan pembelajaran di kelas dipengaruhi oleh banyak faktor, antara lain faktor guru, siswa, media, bahan atau materi dan faktor metode yang digunakan. Beberapa faktor yang harus diperhatikan adalah tingkat kelas, umur, situasi, dan kondisi lingkungan siswa tanpa mengabaikan faktor-faktor lain. Kekuatan yang krusial dalam memulai sebuah pelajaran adalah memotivasi keinginan peserta didik untuk belajar (Moore, 2012:87).

Belajar menurut Zaini, dkk (2008) dapat mengajak peserta didik untuk turut serta dalam semua proses pembelajaran, tidak hanya mental tetapi juga melibatkan fisik. 
Sebenarnya peneliti sebagai pengelola kegiatan pembelajaran sudah berusaha semaksimal mungkin dalam menyampaikan materi sub tema 1 sumber energi.

Berdasarkan pendapat di atas tersebut diharapkan timbul ide-ide baru dan produkproduk yang inovatif (Susiana, 2008). Saat peneliti menjelaskan materi pelajaran tampak sekali siswa memperhatikan dengan sungguh-sungguh. Memang ada satu dua siswa yang bermain sendiri atau bersenda gurau dengan teman sebangku, tetapi setelah diperingatkan guru mereka kembali serius memperhatikan penjelasan peneliti. Sewaktu peneliti memberikan beberapa pertanyaan hubungannya dengan materi dengan serempak mereka menjawab benar. Tetapi sungguh sangat mengecewakan saat dilakukan tes formatif hasilnya sungguh di luar dugaan yaitu dari 33 siswa yang mencapai tuntas belajar hanya 6 siswa atau 18,2\% dengan nilai rata-rata 55,4.

Kenyataan tersebut di atas mendorong peneliti untuk merefleksi diri, merenung dan menganalisis keterangan-keterangan maupun kelemahan-kelemahan yang ada selama kegiatan pembelajaran berlangsung. Peneliti mencoba mencari informasi dengan mengkaji beberapa literatur tentang strategi pembelajaran. Berdiskusi dengan teman sejawat dan melakukan wawancara dengan siswa. Hasil dari usaha tersebut terungkap ada beberapa permasalahan yang harus segera dipecahkan yaitu: (1) Daya serap siswa rendah, (2) Dalam proses pembelajaran siswa kurang diberdayakan sehingga cenderung pasif, (3) Rendahnya minat belajar siswa.

Berdasarkan permasalahan di atas maka peneliti tertarik untuk melakukan perbaikan pembelajaran sub tema 1 sumber energi di kelas IV melalui Penelitian Tindakan Kelas (PTK). Menyadari akan kekurangan yang selama ini peneliti alami dalam mengajarkan materi sub tema 1 sumber energi, dengan berbekalkan kejujuran dan keterbukaan, serta didorong oleh kemauan dan semangat yang tinggi untuk senantiasa mencoba memperbaiki kerja sebagai guru dalam rangka mencapai tujuan pembelajaran yang maksimal dan sesuai dengan kriteria ketuntasan minimal. Peneliti mencoba memperbaiki diagnosis status untuk menemukan kelemahan-kelemahan yang terjadi selama melakukan proses pembelajaran materi sub tema 1 sumber energi di kelas IV SDN 2 Sigli.

Banyak faktor yang mempengaruhi hasil proses pembelajaran seperti yang telah diuraikan di depan. Tetapi dari banyak faktor tersebut kehadiran sosok peneliti di depan kelas bagi siswa-siswi di sekolah dasar merupakan faktor yang sangat penting mengingat tingkat perkembangan kognitif siswa sekolah dasar yang masih memerlukan kehadiran orang dewasa dalam kegiatan belajarnya. Tanpa kehadiran seorang guru sangat tidak mungkin siswa sekolah dasar dapat mandiri melakukan kegiatan belajar. Terbukti kenyataannya hasil tes formatif sub tema 1 sumber energi di kelas IV yang telah peneliti sampaikan begitu jelas hasilnya sungguh sangat memprihatinkan, yaitu dari 33 siswa baru 6 siswa atau 18,2\% yang mencapai tuntas belajar dengan nilai ratarata 55,4 .

Menurut Slameto (2013:54) faktor yang dapat mempengaruhi proses belajar dapat digolongkan menjadi 2 faktor, antara lain faktor internal dan faktor eksternal. Salah satu faktor yang termasuk dalam internal adalah motivasi, sedangkan eksternal yaitu keluarga. Schunk, Pintrich, dan Meece (2008) mengajukan definisi motivasi sebagai "proses di mana aktivitas yang terarah pada suatu tujuan tertentu didorong dan dipertahankan." Motivasi berprestasi atau motivasi untuk berprestasi dengan demikian adalah motivasi yang tujuannya adalah meraih prestasi. Motivasi merupakan suatu tenaga yang mendorong individu melakukan kegiatan untuk mencapai suatu tujuan (Nana dan Erliana, 2012). Dari pendapat tersebut motivasi belajar merupakan pemberian dorongan atau semangat yang menggerakkan siswa melakukan berbagai aktivitas belajar.

Proses pembelajaran dengan alat peraga konvensional kurang dapat meningkatkan 
efektifitas pembelajaran sehingga proses pembelajaran tidak optimal dan kurang kreatif, dan tidak inovatif, dan kurang sesuai dengan perkembangan zaman. Untuk itu diperlukan alat peraga inovatif yang dapat meningkatkan motivasi dan prestasi belajar siswa melalui peningkatan aktifitas siswa dalam proses pembelajaran serta peningkatan pemahaman konsep terhadap materi. Hasil diskusi tersebut adalah mencoba menggunakan media pembelajaran dalam proses pembelajaran sub tema 1 sumber energi.

Media pembelajaran adalah segala sesuatu yang dapat digunakan untuk menyalurkan pesan (bahan pembelajaran), sehingga dapat menarik perhatian, minat, pikiran dan perasaan siswa dalam kegiatan belajar untuk mencapai tujuan pembelajaran tertentu (Kurnia, 2019:65). Terkait dengan media, Daryanto (2011:78) menyatakan bahwa pemilihan media dan metode pembelajaran akan sangat berpengaruh terhadap hasil belajar siswa di samping persepsi siswa sendiri tentang belajar.

Diharapkan melalui penerapan media pembelajaran siswa akan mempunyai gambaran yang jelas terhadap materi pelajaran. Penggunaan buku pelajaran biasa dalam pembelajaran sub tema 1 sumber energi, masih belum memberikan hasil maksimal karena siswa masih harus berfikir abstrak dan menghafal dalam memahami materinya. Penerapan media gambar, dan buku pelajaran tidak mampu memotivasi peserta didik karena media tersebut terbiasa dilihat dan digunakan siswa. Berdasarkan permasalahan, pembelajaran sub tema 1 sumber energi perlu menggunakan media pembelajaran yang lebih inovatif yaitu roda putar puzzle pintar yang dapat meningkatkan hasil belajar siswa.

\section{METODE PENELITIAN}

Rancangan penelitian yang digunakan adalah penelitian tindakan kelas (PTK). PTK ini memiliki tujuan untuk memperbaiki atau meningkatkan mutu (kualitas) pembelajaran di kelas melalui suatu tindakan tertentu dalam satu atau beberapa siklus sesuai yang dibutuhkan. Adapun tahap-tahap penelitian ini menurut Arikunto (2010:131) adalah (1) perencanaan; (2) pelaksanaan dan pengamatan; (3) refleksi. Subjek penelitian ini adalah guru dan siswa kelas IV SDN 2 Sigli yang berjumlah 33 siswa yang terdiri dari 17 siswa laki-laki dan 16 siswa perempuan. Lokasi penelitian ini adalah SDN 2 Sigli.

Teknik pengumpulan data dalam penelitian ini dilakukan dengan: (1) observasi; (2) tes; (3) catatan lapangan. Teknik tersebut digunakan untuk mendeskripsikan pelaksanaan pembelajaran, hasil belajar siswa berupa keterampilan menyimak cerita, mendeskripsikan kendala-kendala selama menggunakan media film kartun dan cara mengatasinya.

Instrumen penilaian yang digunakan adalah: (1) lembar pelaksanaan pembelajaran; (2) lembar tes hasil belajar siswa; (3) lembar catatan lapangan. Lembar pelaksanaan pembelajaran digunakan untuk memperoleh data tentang pelaksaanan pembelajaran dan ketercapaian. Lembar tes hasil belajar siswa digunakan untuk memperoleh data tentang keterampilan menyimak cerita siswa. Catatan lapangan dilakukan untuk mencatat kendala-kendala yang terjadi pada waktu berlangsungnya pembelajaran. Selanjutnya data yang diperoleh akan diolah dan dianalisis secara kualitatif dan kuantitatif.

Data pelaksanaan pembelajaran dianalisis secara kuantitatif menggunakan rumus:

$$
P=\frac{F}{N} \times 100 \%
$$

Keterangan:

$\mathrm{P}=$ Angka persentase

$\mathrm{F}=$ Frekuensi yang sedang dicari persentasenya 
$\mathrm{N}$ = Jumlah frekuensi/ banyak individu

Untuk menghitung nilai rata-rata (mean) dalam penelitian ini, maka penulis menggunakan rumus sebagai berikut:

$$
\bar{X}=\frac{\sum x}{N}
$$

Keterangan :

$\bar{X} \quad=$ Rata-Rata (Mean)

$\sum x=$ Jumlah seluruh skor

$\mathrm{N} \quad=$ Jumlah Individu (Sudjana, 2009:109)

Setiap siswa dikatakan tuntas belajarnya (ketuntasan individu) jika proposi jawaban benar siswa $\geq 65$, dan suatu kelas dikatakan tuntas belajarnya (ketuntasan klasikal) jika di dalam kelas tersebut terdapat $\geq 85 \%$ siswa yang tuntas belajarnya. Dan nilai KKM pada SDN 2 Sigli adalah 70.

\section{HASIL DAN PEMBAHASAN}

Berikut disajikan data hasil observasi aktivitas siswa dalam penggunaan media Roda Putar Puzzle Pintar pada siklus pertama dan kedua.

Tabel 1. Hasil observasi aktivitas siswa pada Siklus I

\begin{tabular}{|c|c|c|c|c|}
\hline No & Aspek yang diamati & $\mathbf{Y a}$ & Tidak & $\begin{array}{c}\text { Catatan } \\
\text { Pengamatan }\end{array}$ \\
\hline 1 & Siswa mendengarkan tujuan pembelajaran & $\checkmark$ & & \\
\hline 2 & $\begin{array}{l}\text { Siswa mengamati gambar yang diberikan } \\
\text { guru }\end{array}$ & $\checkmark$ & & \\
\hline 3 & $\begin{array}{l}\text { Siswa menanya tentang hal-hal yang tidak } \\
\text { mengerti yang ada di dalam gambar }\end{array}$ & $\checkmark$ & & \\
\hline 4 & Siswa memperhatikan penjelasan guru & $\checkmark$ & & \\
\hline 5 & $\begin{array}{l}\text { Siswa membaca bacaan tentang sumber } \\
\text { energi }\end{array}$ & & $\checkmark$ & \\
\hline 6 & Siswa menggapi pertanyaan dari temannya & & $\checkmark$ & \\
\hline 7 & $\begin{array}{l}\text { Siswa mengerjakan LKS yang dibagikan } \\
\text { guru }\end{array}$ & & $\checkmark$ & \\
\hline
\end{tabular}

Berdasarkan tabel di atas dapat dipahami bahwa aktivitas pada siklus I yaitu siswa termotivasi dalam belajar, mendengarkan penjelasan peneliti, bertanya jawab dengan peneliti dan mengerjakan LKS. Namun demikian, pada siklus I belum terjadinya pembelajaran yang aktif, karena pada siklus I ini masih menggunakan metode konvensional, siswa tidak menyukai pembelajaran ini karena proses pembelajaran yang monoton. Siswa terlihat tidak menyukai pembelajaran yang menggunakan metode konvensional, sehingga hasil belajar siswa rendah.

Tabel 2. Hasil observasi aktivitas siswa pada siklus II

\begin{tabular}{|c|c|c|c|}
\hline No & Aspek yang diamati & Tak & $\begin{array}{c}\text { Catatan } \\
\text { Pengamatan }\end{array}$ \\
\hline 1 & $\begin{array}{l}\text { Siswa memulai pembelajaran dengan } \\
\text { berdoa }\end{array}$ & $\checkmark$ & \\
\hline 2 & $\begin{array}{l}\text { Siswa mendengarkan tujuan } \\
\text { pembelajaran }\end{array}$ & $\checkmark$ & \\
\hline 3 & Siswa mengamati gambar yang diberikan & $\checkmark$ & \\
\hline
\end{tabular}




\begin{tabular}{llll}
\hline \multicolumn{2}{l}{ guru } \\
\hline 4 & $\begin{array}{l}\text { Siswa menanya tentang hal-hal yang } \\
\text { tidak mengerti yang ada di dalam gambar }\end{array}$ & $\checkmark$ & \\
\hline 5 & Siswa berkerja sama dalam berdiskusi & $\checkmark$ & $\checkmark$ \\
\hline 6 & $\begin{array}{l}\text { Siswa menggapi pertanyaan dari } \\
\text { temannya }\end{array}$ & $\checkmark$ & \\
\hline 7 & $\begin{array}{l}\text { siswa mengerjakan LKS yang dibagikan } \\
\text { guru }\end{array}$ & $\checkmark$ & \\
\hline 8 & Siswa mengumpulkan LKS & $\checkmark$ & \\
\hline
\end{tabular}

Berdasarkan tabel di atas terlihat bahwa siklus II, siswa mendengarkan tujuan pembelajaran, siswa dibagi dalam beberapa kelompok, siswa melakukan berdiskusi, siswa menuliskan pertanyaan pada lembar kerja serta mengerjakan LKS.

Dengan pembelajaran menerapkan media roda putar puzzle pintar berdasarkan hasil observasi tehadap siswa menunjukkan aktivitas siswa bertanya, mencatat, membawa sumber buku, mencari informasi, melaksanakan tugas guru mengkomunikasikan hasil, konsentrasi dalam pembelajaran, dan merespon pertanyaan guru kemunculannya cukup terlihat jelas. Fakta ini sesuai dengan yang dikemukakan Suyono (2015) bahwa keberhasilan penggunaan media pembelajaran dalam proses pembelajaran di kelas sangat dipengaruhi pula oleh gaya guru menyajikan materi pelajaran melalui pemanfaatan media, sifat media, tantangan media, modifikasi media, dan kebermanfaatan media.

Melalui penerapan media roda putar puzzle pintar, siswa tidak mengalami kesulitan yang berarti karena telah terbiasa melakukan keterampilan yang dimaksud. Ini sesuai dengan pendapat yang dikemukakan oleh Hamalik (2009) bahwa siswa dapat memperoleh lebih banyak pengalaman dengan cara keterlibatan secara aktif dan personal, dibandingkan dengan bila mereka hanya melihat materi atau konsep.

Sejalan dengan Sa'dun Akbar (2013:117), media pada dasarnya adalah alat bantu penyampai pesan pembelajaran yang mengarah pada tujuan pembelajaran. Setelah kegiatan belajar mengajar, penulis mengadakan tes akhir untuk mengetahui keberhasilan penggunaan media roda putar puzzle pintar. Dari hasil tes tersebut maka diperoleh rincian nilai setiap siswa pada tabel di bawah ini:

\begin{tabular}{cccccc}
\hline Siklus & Tuntas & Persen & Belum & Persen & Nilai Rata-rata \\
\hline Pra Siklus & 6 & 18,2 & 27 & 81,8 & 55,4 \\
\hline I & 16 & 48,5 & 17 & 51,5 & 68,2 \\
\hline II & 28 & 84,9 & 5 & 15,1 & 77,6 \\
\hline
\end{tabular}

Dari data tersebut terlihat dari tiap-tiap siklus pada umumnya hasil belajar siswa mengalami kenaikan. Dari 33 siswa pada saat pra siklus hanya 6 siswa $(18,2 \%)$ siswa yang mengalami keberhasilan dalam belajar, sedangkan sisanya 27 siswa $(81,8 \%)$ mengalami kegagalan atau tidak tuntas. Pada siklus-1 tercatat yang mengalami ketuntasan hasil belajar sebanyak 16 siswa (48,5\%) sedangkan 17 siswa (51,5\%) dinyatakan belum tuntas.

Pada siklus-2, perubahan semakin terlihat jelas yaitu siswa yang mencapai ketuntasan tercatat 28. Pada awal siklus-1, ketuntasan belajar siswa belum mampu memenuhi KKM yang membatasi minimal $75 \%$ siswa tuntas dalam pembelajaran sub tema 1 sumber energi. Hal ini disebabkan karena nilai evaluasi post test siswa yang kurang baik sehingga akan sangat berpengaruh pada nilai rata-rata. Data hasil penelitian menunjukkan peningkatan nilai rata-rata siswa yakni dari 68,2 pada siklus-1 menjadi 77,6 pada siklus-2.

Nilai ini disebabkan oleh meningkatnya motivasi siswa dalam mengikuti kegiatan 
pembelajaran sub tema 1 sumber energi. Seperti yang dinyatakan oleh Djamarah (2010:148) menjelaskan ada enam hal yang dapat dikerjakan oleh guru untuk membangkitkan gairah belajar anak didik, yaitu: membangkitkan dorongan kepada anak didik untuk belajar; menjelaskan secara konkret kepada anak didik apa yang dapat dilakukan pada akhir pengajaran; memberikan ganjaran terhadap prestasi yang dicapai anak didik sehingga dapat merangsang untuk mendapat prestasi yang lebih baik di kemudian hari; membentuk kebiasaan belajar yang baik; membantu kesulitan belajar anak didik secara individual maupun kelompok; serta menggunakan metode yang bervariasi.

Hal ini selaras dengan pernyataan Uno (2010:23) bahwa motivasi dan belajar merupakan dua hal yang saling mempengaruhi. Belajar adalah perubahan tingkah laku secara relatif permanen dan secara potensial terjadi sebagai hasil dari praktik atau penguatan yang dilandasi tujuan untuk mencapai tujuan tertentu. Perbandingan ketuntasan hasil belajar sub tema 1 sumber energi pra tindakan, siklus-1, dan siklus-2 tersebut dapat disajikan pada grafik di bawah ini.

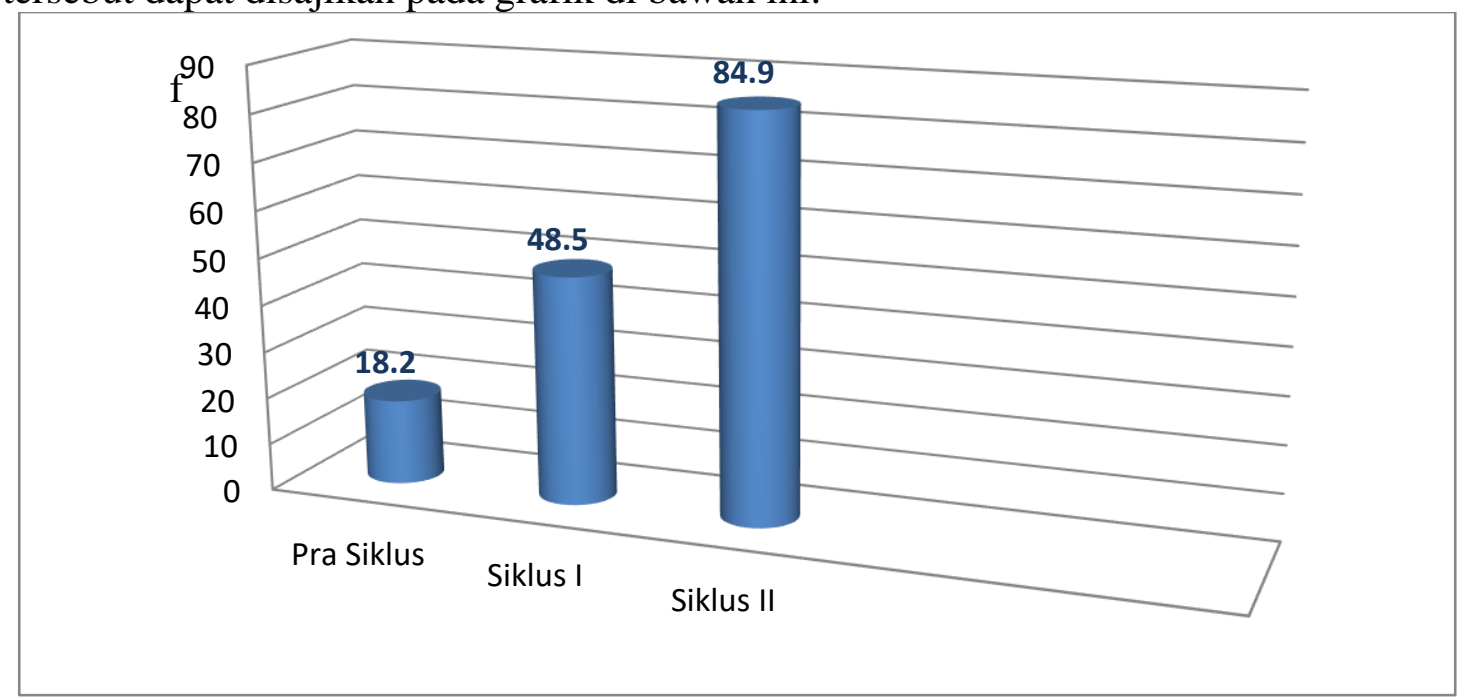

Gambar Grafik Perbandingan Ketuntasan Hasil Belajar Siswa Pra Tindakan, Siklus-1 dan Siklus-2

Dari grafik tersebut, diketahui bahwa tingkat prosentase ketuntasan siswa saat kondisi pra siklus sampai siklus-2 mengalami peningkatan. Pada siklus I penerapan media roda putar puzzle pintar masih belum maksimal dan siswa baru mengenal untuk pertama kalinya sehingga dalam penggunaannya masih belum paham sehingga prosentase ketuntasan siswa baru mencapai 48,5\%. Pada siklus-2 guru mencoba menerapkan permainan cerdas pintar dengan menggunakan media roda putar puzzle pintar dan hasilnya cukup menggembirakan. Tingkat prosentase ketuntasan siswa mencapai 84,9\%. Hal ini sesuai dengan pendapat Ega Rima Wati (2016:2) media sebagai alat bantu yang dapat digunakan sebagai penyampai pesan untuk mencapai tujuan pembelajaran.

Dengan adanya media inovatif maka motivasi dan prestasi belajar meningkat, seperti yang diungkapkan Iskandar Agung (2010:38) terdapat sejumlah hal yang mungkin dapat menjadi pedoman atau acuan bagi guru untuk membangkitkan perhatian dan motivasi belajar peserta didik yaitu: (1) mengkaji rancangan dan persiapan bahan ajar/materi pelajaran dan tujuan pembelajaran; (2) merancang cara yang akan digunakan; (3) merancang penggunaan gaya bahasa yang sederhana, segar, komunikatif, dan tidak monoton, tidak membosankan serta mudah dicerna; (4) merancang penciptaan suasana interaksi belajar mengajar yang luwes dan bersahabat; (5) merancang bentuk pertanyaan yang bersifat membimbing (direction question) dan memunculkan rasa keingintahuan; (6) merancang bentuk pujian verbal atau nonverbal terhadap siswa yang 
memperlihatkan perhatian dan motivasi belajar yang baik; (7) merancang metode dan media pembelajaran variatif; dan (8) merancang tugas/pekerjaan yang akan diberikan dalam pembelajaran.

Perbandingan ketidaktuntasan hasil belajar IPS materi kenampakan alam dan keadaan sosial negara tetangga pra tindakan, siklus-1, dan siklus-2 tersebut dapat disajikan pada grafik di bawah ini.

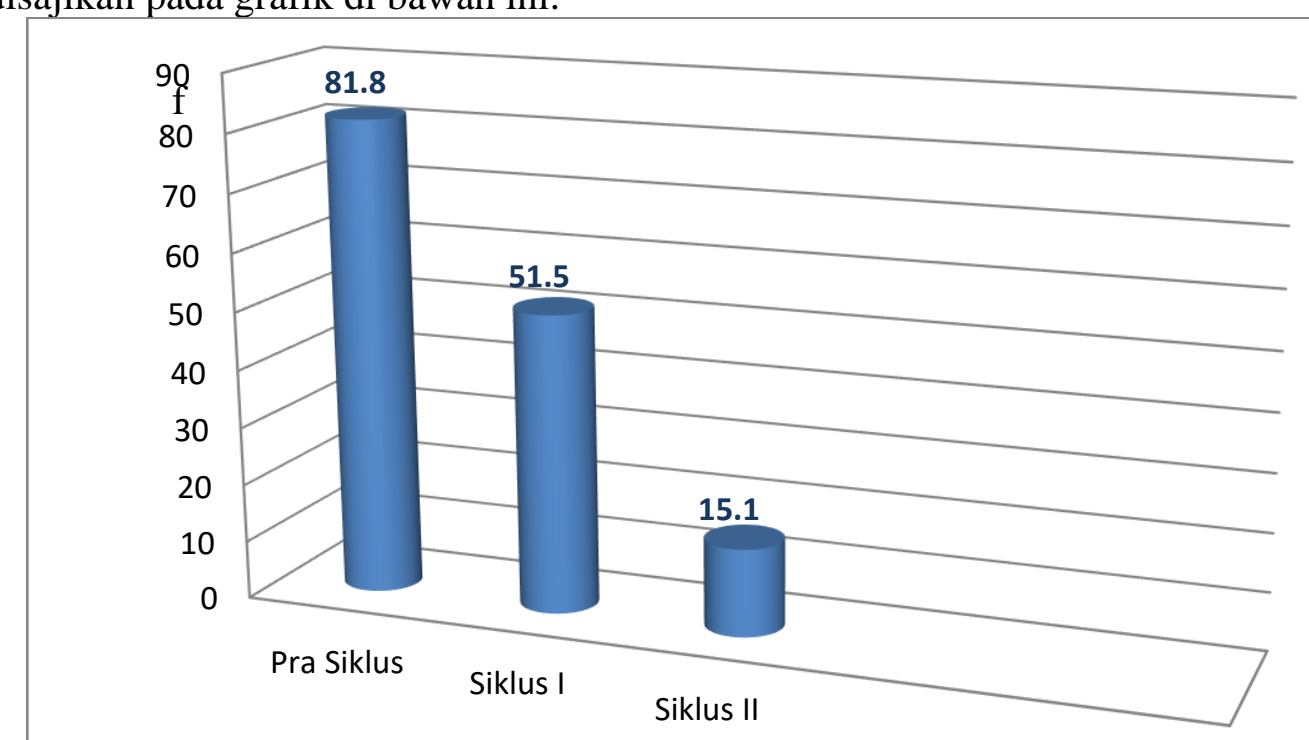

Gambar Grafik Perbandingan Ketidaktuntasan Hasil Belajar Siswa Pra Tindakan, Siklus-1 dan Siklus-2

Dari hasil tindakan siklus I dan siklus II dan masih dengan media yang sama dikombinasi permainan cerdas pintar menunjukkan terjadinya penurunan ketidaktuntasan hasil belajar siswa. Hal tersebut karena guru dalam menyampaikan materi pembelajaran menggunakan media roda putar puzzle pintar. Penggunaan media pembelajaran yang tepat dapat membantu proses penyampaian informasi atau pesan dalam pembelajaran berlangsung secara efektif (Sunaengsih, 2016:184). Penggunaan media akan berpengaruh pada motivasi belajar siswa.

Dengan motivasi belajar yang tinggi mampu meningkatkan prestasi siswa. Seperti yang dikemukakan Sudjana (2009) bahwa nilai-nilai praktis media pengajaran adalah: (1) dengan media dapat meletakkan dasar-dasar yang nyata untuk berpikir sehingga dapat mengurangi verbalisme; (2) dengan media dapat memperbesar minat dan perhatian siswa untuk belajar; (3) dengan media dapat meletakkan dasar untuk perkembangan belajar sehingga hasil belajar bertambah mantap; (4) memberikan pengalaman yang nyata dan dapat menumbuhkan kegiatan berusaha sendiri pada setiap siswa; (5) menumbuhkan pemikiran yang teratur dan berkesinambungan; (6) membantu tumbuhnya pemikiran dan memantau berkembangnya kemampuan berbahasa; (7) memberikan pengalaman yang tak mudah diperoleh dengan cara lain serta membantu berkembangnya efisiensi dan pengalaman belajar yang lebih sempurna; (8) bahan pengajaran akan lebih jelas maknanya, sehingga dapat lebih dipahami oleh para siswa, dan memungkinkan siswa menguasai tujuan pengajaran lebih baik; (9) metode mengajar akan lebih bervariasi, tidak sematamata komunikasi verbal melalui penuturan kata-kata oleh guru, sehingga siswa tidak bosan dan guru tidak kehabisan tenaga, apalagi bila guru mengajar untuk setiap jam pelajaran; (10) siswa lebih banyak melakukan kegiatan belajar, sebab tidak hanya mendengarkan uraian guru, tetapi juga aktivitas lain seperti mengamati, melakukan, mendemonstrasikan, dan lain-lain.

Berdasarkan uraian di atas, dapat dilihat bahwa penerapan media roda putar puzzle pintar dapat meningkatkan motivasi dan prestasi belajar sub tema 1 sumber 
energi. Dengan demikian penelitian sudah tidak dilanjutkan atau berakhir. Penelitian ini berakhir dengan meningkatnya hasil belajar sub tema 1 sumber energi pada kelas SDN 2 Sigli. Tingginya kemampuan pemahaman konsep siswa diduga disebabkan oleh media roda putar puzzle pintar dalam pembelajaran yang telah digunakan secara efektif.

\section{PENUTUP}

Penerapan media roda putar puzzle pintar pada pelaksanaan pembelajaran sub tema 1 sumber energi Kelas VI, dapat meningkatkan aktivitas siswa yang meliputi: bertanya, mencatat, membawa sumber buku, mencari informasi, melaksanakan tugas guru, mengkomunkasikan hasil, konsentrasi dalam pembelajaran, dan merespon pertanyaan guru. Penerapan media roda putar puzzle pintar dapat meningkatkan prestasi belajar siswa dimana pada saat kondisi pra siklus, nilai rata-rata hasil belajar siswa sebelum tindakan yakni 55,4. Kemudian pada siklus I, nilai ini meningkat menjadi 68,2. Hasil cukup signifikan terjadi pada siklus II yaitu nilai ratarata siswa mencapai 77,6.

\section{DAFTAR PUSTAKA}

Agung, Iskandar. (2010). Meningkatkan Kreativitas Pembelajaran Bagi Guru. Jakarta: Bestari Buana.

Darsono, M. (2000). Belajar dan Pembelajaran. Semarang: IKIP Semarang Press.

Djamarah, S. B. \& Aswan Z. (2010). Strategi Belajar Mengajar. Jakarta: Rineka Cipta.

Darmawan, D., (2013). Teknologi Pembelajaran. Bandung: PT. Remaja Rosdakarya.

Daryanto. (2011). Media Pembelajaran. Bandung: Sarana Tutorial Nurani.

Oemar Hamalik. 2007. Proses Belajar Mengajar. Bumi Aksara, Jakarta.

Schunk, D. H., Pintrich, P. R., \& Meece, J. L. (2008). Motivation in Education, Theory, Research, and Applications. Third Edition. New Jersey: Pearson Educatuon, Inc.

Slameto. (2015). Belajar dan Faktor-Faktor Yang Mempengaruhinya. Jakarta: Penerbit Rineka Cipta.

Sudjana, N. (2009). Penilaian Hasil Proses Belajar Mengajar. Bandung: Remaja Rosda Karya.

Sukmadinata, N. S dan Erliana. S. (2012). Kurikulum \& Pembelajaran Kompetensi. Bandung: PT Refika Aditama.

Sunaengsih, Cucu. (2016). Pengaruh Media pembelajaran Terhadap Mutu Pembelajaran pada Sekolah Dasar Terakreditasi A. Jurnal Mimbar Sekolah. Vol. 3, No. 2.

Susiana, Nancy. (2013). Program Pembelajaran Kimia Tentang Menumbuhkan Sikap Wirausaha Siswa SMA. UPI Digital Library. Diakses tanggal 30 November 2020.

Suyono \& Hariyanto. (2011). Belajar dan Pembelajaran. Bandung: Remaja Rosdakarya.

Uno, Hamzah B. 2008. Teori Motivasi dan Pengukurannya: Kajian dan Analisis di Bidang Pendidikan. Jakarta: Bumi Aksara.

Zaini, Hisyam., Bermawy Munthe dan Sekar Ayu Aryani. (2013). Strategi Pembelajaran Aktif. Jurnal Pendidikan Biologi Unnes. Vol. 5, No. 1. 